Bidik: Jurnal Pengabdian kepada Masyarakat | Vol. 1 No. 2 April 2021

$57-60$

DOI: https://doi.org/10.31849/bidik.v1i2.6569

\title{
Pengenalan Dan Pelatihan SLiMS 9 Bulian untuk Pustakawan Sekolah di Kota Pekanbaru
}

\author{
Eko Noprianto*, Rismayeti** \\ Fakultas Ilmu Budaya, Universitas Lancang Kuning \\ *E-mail : ekonoprianto@,unilak.ac.id
}

\begin{abstract}
This service activity aims to provide understanding and training to school librarians in Pekanbaru City. A common problem for partners is that they do not have adequate skills in operating SLiMS 9 Bulian. This service activity is expected to increase the understanding and skills of school librarians in Pekanbaru City regarding the operation of SLiMS 9 Bulian. The output produced according to this activity plan is in the form of scientific articles. The method of implementing activities is counseling. Submission of material is carried out by lecturers who are members of the team that propose community service activities. Based on the results of this activity, it can be concluded that there is an increase in the understanding and skills of participants in operating SLiMS 9 Bulian. Although in this activity participants can not attend with the maximum online, disorders caused by internet network.
\end{abstract}

Keywords: Senayan, slims 9 bulian, school librarian, introduction of slims, Pekanbaru

\begin{abstract}
Abstrak
Kegiatan pengabdian ini bertujuan untuk memberikan pemahaman dan pelatihan kepada pustakawan sekolah di Kota Pekanbaru. Permasalahan umum pihak mitra ialah belum memiliki keterampilan yang memadai dalam mengoperasikan SLiMS 9 Bulian. Kegiatan pengabdian ini diharapkan dapat meningkatkan pemahaman dan dan keterampilan pustakawan sekolah di Kota Pekanbaru tentang pengoperasian SLiMS 9 Bulian. Luaran yang dihasilkan sesuai rencana kegiatan ini yaitu berupa artikel ilmiah. Adapun metode pelaksanaan kegiatan ialah penyuluhan. Penyampaian materi dilakukan oleh dosen yang tergabung dalam tim pengusul kegiatan pengabdian kepada masyarakat. Berdasarkan hasil kegiatan ini dapat disimpulkan bahwa terdapat peningkatan pemahaman dan keterampilan peserta dalam mengoperasikan SLiMS 9 Bulian. Meskipun dalam kegiatan ini peserta tidak dapat mengikuti acara dengan maksimal secara daring, yang disebabkan oleh gangguan jaringan internet.
\end{abstract}

Kata kunci: Senayan; slims 9 bulian; pustakawan sekolah; pengenalan slims; Pekanbaru

\section{Pendahuluan}

Kemajuan teknologi mengakibatkan adanya perubahan dalam pengelolaan dan pelayanan perpustakaan. Pada saat ini, mayoritas perpustakaan melakukan pengelolaan dan pelayanan menggunakan sistem otomasi. Otomasi perpustakaan sangat penting untuk meningkatkan efisiensi kerja dan layanan di perpustakaan. Pemerintah juga mendukung pengembangan perpustakaan dengan memanfaatkan teknologi, yang dituangkan dalam Undang-Undang Nomor 
43 tentang perpustakaan: "Setiap perpustakaan mengembangkan layanan perpustakaan sesuai dengan kemajuan teknologi informasi dan komunikasi”.

Aplikasi untuk membangun sistem otomasi perpustakaan sudah banyak diciptakan oleh para pegiat perpustakaan, salah satunya adalah Senayan Library Management System (SLiMS). SLiMS adalah perangkat lunak yang banyak digunakan untuk membantu pengolahan bahan pustaka ataupun sebagai sistem otomasi perpustakaan. SLiMS merupakan perangkat lunak jenis sumber terbuka (open source software) yang dikembangkan secara berkelanjutan oleh Senayan Developer Community. Pada Februari 2020, Senayan Developer Community kembali merilis SLiMS versi terbaru yaitu SLiMS 9 Bulian, yang memiliki beberapa fitur baru dan tampilan yang berdeda dengan versi terdahulu.

Pustakawan sebagai tenaga pengelola perpustakaan harus mengikuti perkembangan tersebut, artinya pustakawan harus mengenal dan mampu mengoperasikanSLiMS versi 9 Bulian. Sejalan dengan amanat Undang-Undang Nomor 43 tentang Perpustakaan bahwa pustakawan harus memiliki kompetensi dibidang kepustakawanan serta mempunyai tugas dan tanggung jawab untuk melaksanakan pengelolaan dan pelayanan perpustakaan. Berdasarkan hal tersebut, perlu dilakukan pengenalan dan pelatihan dalam mengoperasikan SLiMS 9 Bulian kepada pustakawan. Tujuannya adalahmemberikan pengetahuan dan membina kompetensi pustakawan dalam mengelola perpustakaan.

\section{Permasalahan Mitra}

Permasalahan umum pihak mitra ialah belum memiliki keterampilan yang memadai dalam mengoperasikan SLiMS 9 Bulian.

\section{Persoalan Prioritas dan Konsep}

Sejalan dengan permasalahan di atas maka persoalan prioritas adalah memberikan pengetahuan dan keterampilan kepada pustakawan sekolah untuk mengoperasikan SLiMS 9 Bulian tersebut.

\section{Pendekatan Pelaksanaan Program}

Adapun metode pelaksanaan kegiatan ialah memberikan keterampilan dalam menggunakan SLiMS 9 Bulian kepada pustakawan sekolah. Penyampaian materi dilakukan oleh dosen yang tergabung dalam tim pengusul kegiatan pengabdian kepada masyarakat. Selain itu kegiatan dalam rangka pengabdian kepada masyarakat menggunakan dua metode, yaitu 1) Ceramah atau penyuluhan. Dalam metode ini penceramah atau penyuluh menyampaikan materi tentang pengenalan SLiMS 9 Bulian. Dalam kesempatan itu peserta dibebaskan untuk bertanya jawab dengan pemateri . Rincian dari metode ini ialah pemaparan mengenai fitur-fitur baru pada SLiMS 9 Bulian beserta fungsinya. 2) Dialog interaktif, dalam hal ini peserta diposisikan sebagai subjek yang dapat memberikan ulasan terkait dengan SLiMS 9 Bulian. Dialog ini sebagai curah pendapat (brainstorming) dari peserta untuk memperoleh masukan berupa persoalan, aspirasi, usulan, gagasan dan solusi. 3) Penyebaran kuisioner sebelum dan sesudah dilaksanakannya penyuluhan (kuisioner pretest dan 
posttest). Tujuan dilaksanakannya penyebaran kuisioner ini adalah untuk mendapatkan perbandingan pengetahuan dan wawasan peserta tentang SLiMS 9 Bulian.

\section{Prosedur Kerja}

Prosedur kerja yang akan dilaksanakan dengan beberapa tahap, yaitu Pertama, tahap persiapan. Persiapan ini difokuskan dengan menyiapkan semua peralatan yang dibutuhkan untuk melaksanan kegiatan ini, studi literatur dan melakukan koordinasi dengan organisasi terkait untuk melakukan kegiatan. Kedua, kunjungan ke lokasi untuk menentukan tempat (lokasi) kegiatan pelatihan. Ketiga, perancangan materi Pengenalan dan Pelatihan SLiMS 9 Bulian dengan mempersiapkan materi yang akan ditampilkan dalam kegiatan. Modul diperbanyak sejumlah peserta yang terlibat dalam kegiatan.

Keempat, pelaksanaan dilakukan oleh tim pelaksana Pengabdian dari Universitas Lancang Kuning. Adapun yang menjadi ukuran keberhasilan kegiatan ini, yakni 1) Terwujudnya kerja sama antara pelaksana kegiatan dengan pihak mitra, 2) Jumlah peserta yang hadir minimal 50\% dari undangan, 3) Adanya interaksi dua arah dalam kegiatan antara pembicara dan peserta, 4) Meningkatnya pemahaman peserta terkait dengan materi yang disampaikannya, 5) Peningkatan pemahaman peserta kegiatan diukur dengan penyebaran kuesioner sebelum dansesudah kegiatan.

\section{Refleksi Capaian Program}

\section{Hasil yang dicapai}

Kegitan ini dilaksanakan secara daring menggunakan aplikasi Zoom Meeting pada tanggal 10 Desember 2020, yang diikuti oleh 59 orang peserta ataupun pustakawan dari berbagai sekolah yang ada di Kota Pekanbaru. Kegiatan ini terlaksana dengan baik dan memperoleh beberapa hasil yang telah dicapai.

Tahap pertama, peserta diberikan kuesioner pretest melalui google form dan diberikan waktu selama 10 menit untuk mengisinya. Setelah itu dilanjutkan dengan kata pengantar dan penjelasan tentang "Pengenalan dan Pelatihan SLiMS9 Bulian untuk Pustakawan Sekolah di Kota Pekanbaru" dari tim pengabdian.

Tahap kedua, peserta menyimak pemaparan materi yang disampaikan oleh Tim Pengabdian yang berlansung selama 60 menit, dan dilanjutkan praktik penggunaan SLiMS 9 Bulian selama 120 menit.

Tahap ketiga, peserta diberikan kesempatan bertanya dan menyampaikan kendala yang dihadapi dalam menjalankan tugas sebagai pustakawan terkait otomasi dan penggunaan aplikasi SLiMS. Pada tahap ketiga peserta juga diberikan posttest dan mengisi absensi.

\section{Luaran yang dicapai}

Evaluasi didapatkan dari hasil kuesioner yang diisi peserta sebelum dan sesudah pelatihan. Jawaban kuesioner ini menggambarkan bagaimana pemahaman peserta terhadap materi yang telah disajikan. Untuk lebih jelasnya dapat dilihat rekapitulasi jawaban peserta pada tabel berikut: 
Tabel 1. Hasil Uji Pretest dan Postest

\begin{tabular}{|c|l|c|c|}
\hline No & \multicolumn{1}{|c|}{ Item Pertanyaan } & Pretest & Posttest \\
\hline 1 & $\begin{array}{l}\text { Apakah anda mengetahui fitur-fitur baru pada } \\
\text { SLiMS 9 Bulian? }\end{array}$ & 11 & 36 \\
\hline 2 & $\begin{array}{l}\text { Apakah anda menguasai fitur copy cataloging pada } \\
\text { SLiMS 9 Bulian? }\end{array}$ & 2 & 15 \\
\hline 3 & $\begin{array}{l}\text { Apakah anda mampu menggunakan fitur "News } \\
\text { Library" pada SLiMS 9 Bulian? }\end{array}$ & 7 & 19 \\
\hline 4 & $\begin{array}{c}\text { Apakah anda menguasai menu system pada SLiMS } \\
\text { 9 Bulian? }\end{array}$ & 4 & 21 \\
\hline 5 & $\begin{array}{l}\text { Apakah anda menguasai menu pelaporan pada } \\
\text { SLiMS 9 Bulian? }\end{array}$ & 5 & 23 \\
\hline
\end{tabular}

Berdasarkan tabel di atas dapat diuraikan bahwa hasil posttest menunjukan sekitar 36 atau setara 61\% peserta telah mengetahui fitur-fitur baru yang ada pada SLiMS 9 Bulian. Secara keseluruhan jawaban peserta menggambarkan ada peningkatan pengetahuan dan pemahan peserta terhadap SLiMS 9 Bulian. Namun hasil yang didapatkan belum ada yang mencapai 100\%, karena kegiatan pengabdian ini dilaksanakan secara daring. Beberapa peserta terkendala dengan jaringan internet, sehingga tidak bisa mengikuti kegiatan dengan maksimal.

\section{Penutup}

\section{Kesimpulan}

Berdasarkan uraian di atas dapat disimpulkan bahwa kegiatan pelatihan yang telah dilaksanakan memberikan manfaat terhadap peserta. Hal ini dapat dilihat melalui hasil pretest dan posttest, yang membuktikan adanya peningkatan pemahaman dan keterampilan peserta dalam mengoperasikan SLiMS 9 Bulian. Meskipun dalam kegiatan ini peserta tidak dapat mengikuti acara dengan maksimal secara daring yang disebabkan oleh gangguan jaringan internet. Peserta pada kegiatan ini juga mengusulkan kepada Tim pelaksana untuk mengadakan pelatihan tentang upgrade aplikasi SLiMS, dari versi sebelumnya ke versi yang terbaru.

\section{Saran}

Setelah kegiatan ini dilaksanakan diharapkan peserta:

a. Menerapkan sistem otomasi perpustakaan menggunakan SLiMS 9Bulian dan mengaplikasikan ilmu yang sudah didapatkan.

b. Lebih aktif mengikuti komunitas atau grup pustakawan yang berfokus pada peningkatan kemampuan dalam otomasi perpustakaan.

\section{Daftar Pustaka}


Senayan Developer Community, 2020. Dokumentasi Penggunaan SLiMS 9 Bulian. Diakses pada 10 September 2020, dari https://slims.web.id/.

Perpustakaan Nasional RI. 2007. Undang-Undang Nomor 43 Tahun 2007 tentang Perpustakan. Jakarta: Perpustakaan Nasional RI. 